\title{
Sri Lanka's Aruwakkalu fossil deposit dates to the Burdigalian Age
}

\author{
Ranjeev Epa ${ }^{1}$, Nilmani Perera ${ }^{1}$, Kelum Manamendra-Arachchi ${ }^{2}$ and Madhava Meegaskumbura $^{1}$ * \\ ${ }^{1}$ Department of Zoology, Faculty of Science, University of Peradeniya, Sri Lanka \\ ${ }^{2}$ Postgraduate Institute of Archaeology, 407 Bauddhaloka Mawatha, Colombo 07, Sri Lanka \\ Accepted 08 November 2011
}

\begin{abstract}
Aruwakkalu fossil bed is a part of Sri Lanka's Jaffna limestone, which underlies the whole of Jaffna Peninsula and extends southwards mostly along the west coast. Previous authors have suggested that Aruwakkalu contains a rich assemblage of vertebrate and invertebrate fossils. We sought to confirm the Burdigalian age of this northwestern Miocene deposit at Aruwakkalu on the basis of the foraminifer Pseudotaberina malabarica, an index fossil of the Burdigalian stage. General and timeline collections were made at seven selected sites and the fossils collected were identified. The study sites contained six sedimentary layers of which, third and sixth from top were fossiliferous. The sixth (deepest) layer was dominated by gastropod fossils while the third was dominated by fossils of giant oysters. Fossils of $P$. malabarica were recovered both from timeline and general collections. In the timeline collection, samples of this index fossil were recovered only from the gastropod layer, suggesting that $P$. malabarica existed during the time the gastropod layer was being laid down, thus confirming a Burdigalian age for the latter, and helping to date a substantial portion of the Sri Lankan fossil fauna with confidence.
\end{abstract}

Key words: Pseudotaberina malabarica, foraminifera, index fossil, Miocene, gastropod layer, oyster layer

\section{INTRODUCTION}

Cenozoic era, also known as Age of Mammals (Deraniyagala, 1969a) comprises two periods, the Tertiary (65.5-2.6 mya) and the Quaternary (2.6 mya to the present). The Miocene epoch (23.0-5.3 mya), a subdivision of the Tertiary, was an important phase in Sri Lanka's geological and faunal history. The island was a part of the Indian peninsula until the Miocene, when a belt of sea inundated the southeastern part of the Indian plate (Madduma Bandara, 1989), separating Sri Lanka from the mainland for the first time.

Sri Lanka contains two Tertiary deposits (Fig. 1) dated to the Miocene by Wayland (see Deraniyagala, 1969a). These marine deposits occur in two well-separated localities, one towards the northwest and the other towards the southeast extremity of the island. They are indications of a Tertiary marine transgression, of which the former resulted in the first separation of Sri Lanka from the Indian mainland. Sri Lanka's Miocene deposits classified as Jaffna limestone are formed of two facies: the calcareous and the areno-argillaceous (Deraniyagala, 1969a). The former is found as a broad exposure throughout the Jaffna peninsula and adjacent islands. It extends south along the west coast, gradually thinning out in width. The southernmost major exposure of the Jaffna bed is seen at Karativu, but the eastern border cannot be determined with accuracy due to lack of outcrops (Cooray, 1984). Lithologically, Jaffna limestone typically consists of hard, partly crystalline, compact, indistinctly bedded, creamcoloured rock and is generally at surface level with cliffs in areas such as Kirimalai, Kolanakanatta and Moderagam Aaru (Cooray, 1984).

While a number of Miocene vertebrates and invertebrates have been described from Aruwakkalu, a part of the Jaffna limestone located $25 \mathrm{~km}$ north of Puttalam, these have not been dated so far. This study was conducted within the Quarry of Holcim (Lanka) Ltd., a company extracting limestone for the production of cement. Aruwakkalu has been subjected to strong elevational changes, probably due to block faulting, which is evident in the positioning of the islands along the Kalpitiya shoreline and the ridges along the eastern shore of Dutch Bay. Although the Jaffna bed is considered to be a marine deposit, fossils of terrestrial reptiles and mammals, often associated with estuarine habitats, have also been discovered from the "Malu member", located along the eastern shoreline of Dutch Bay. This suggests that, at least in some areas,

*Corresponding author's email: madhava_m@mac.com 
fossil accumulation took place under fluvial and estuarine conditions (Deraniyagala, 1969a).

Index fossils are fossil taxa that have a wide geographic distribution and show changes in characters, which can be recognized as a part of the temporal scale. Taxa belonging to foraminifera have been present since Cambrian. Planktonic foraminifera have a wide geographic distribution and a rapid evolutionary rate. Therefore they possess a short vertical stratigraphic time range, enabling them to be used as index fossils for dating (BoudagherFadel, 2008). The larger benthic foraminifera, which possess a more complex internal test (shell) structure, are also used as index fossils. These are as successful as planktonic foraminifera and are more abundant in modern seas (Boudagher-Fadel, 2008). The large benthic fossil foraminifer Pseudotaberina malabarica, an index fossil of the Burdigalian stage (Kulkarni et al., 2010), was used to date the Jaffna limestone to this stage of the Miocene, which gives it a temporal range of 20.43-15.97 Ma.
Fossilized tests of the benthic foraminifer Pseudotaberina malabarica are dimorphic owing to alternation of generations in their reproductive life cycle (Banner and Highton, 1989). This is a characteristic feature of large and medium sized benthic foraminifera. However, planktonic foraminifera lack evidence of dimorphism and seem to reproduce sexually (Hottinger, 2006). Dimorphic forms have two test types, the megalospheric and the microspheric. Foraminiferal gamonts and schizonts produced by asexual reproduction are megalospheric with a large proloculus (initial chamber) called the megalosphere, but the overall test diameter is relatively small. Agamonts produced by sexual reproduction, however, are microspheric with a small proloculus and a relatively large overall test diameter (Hottinger, 2006).

The objective of this study was to explore for the presence of Pseudotaberina malabarica in Jaffna limestone at Aruwakkalu so that this deposit can be confidently dated, while also building a reference collection with which future collections could easily be compared.

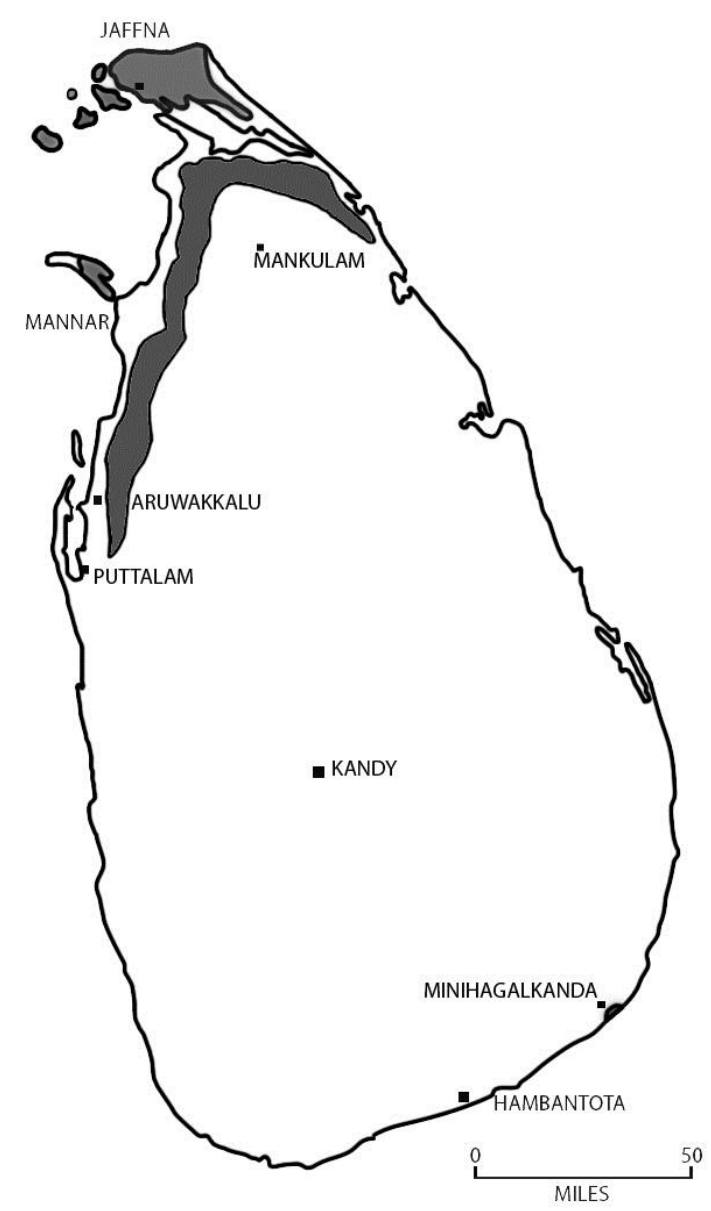

Figure 1. Miocene deposits of Sri Lanka (modified from Cooray, 1984). 


\section{MATERIALS AND METHODS}

\section{Study area and sites}

This study was conducted within the boundaries of the limestone Quarry at Aruwakkalu situated $25 \mathrm{~km}$ north of Puttalum. Study sites were selected based on the exposure of fossiliferous layers and priority was given to areas where the entire soil profile was available. Seven sites (Fig. 2) were surveyed and the Quarry Office $\left(8^{\circ} 14^{\prime} 37.60^{\prime \prime} \mathrm{N} 79^{\circ} 49^{\prime} 25.52^{\prime \prime} \mathrm{E}\right)$ was used as the base point. The sites were named as follows, Peella ( $\left.8^{\circ} 14^{\prime} 31.26^{\prime \prime} \mathrm{N} 79^{\circ} 49^{\prime} 7.59^{\prime \prime} \mathrm{E}\right)$, Alahakoon $\left(8^{\circ} 14 ' 53.34^{\prime \prime N} \quad 79^{\circ} 49^{\prime} 2.89^{\prime \prime} \mathrm{E}\right)$, Water hole $\left(8^{\circ} 15^{\prime} 12.95^{\prime \prime N} \quad 79^{\circ} 48^{\prime} 58.13^{\prime \prime E}\right), \quad$ Coral $\left(8^{\circ} 14^{\prime} 17.10^{\prime \prime} \mathrm{N} \quad 79^{\circ} 48^{\prime} 55.50 " \mathrm{E}\right), \quad$ Beach $\left(8^{\circ} 15^{\prime} 6.30^{\prime \prime} \mathrm{N} \quad 79^{\circ} 48^{\prime} 46.68^{\prime \prime} \mathrm{E}\right), \quad$ Lasantha $\left(8^{\circ} 144^{\prime} 46.06^{\prime \prime N} 79^{\circ} 49^{\prime} 12.52^{\prime \prime E}\right)$, and Working (8॰15'19.23"N 79॰49'9.16"E).
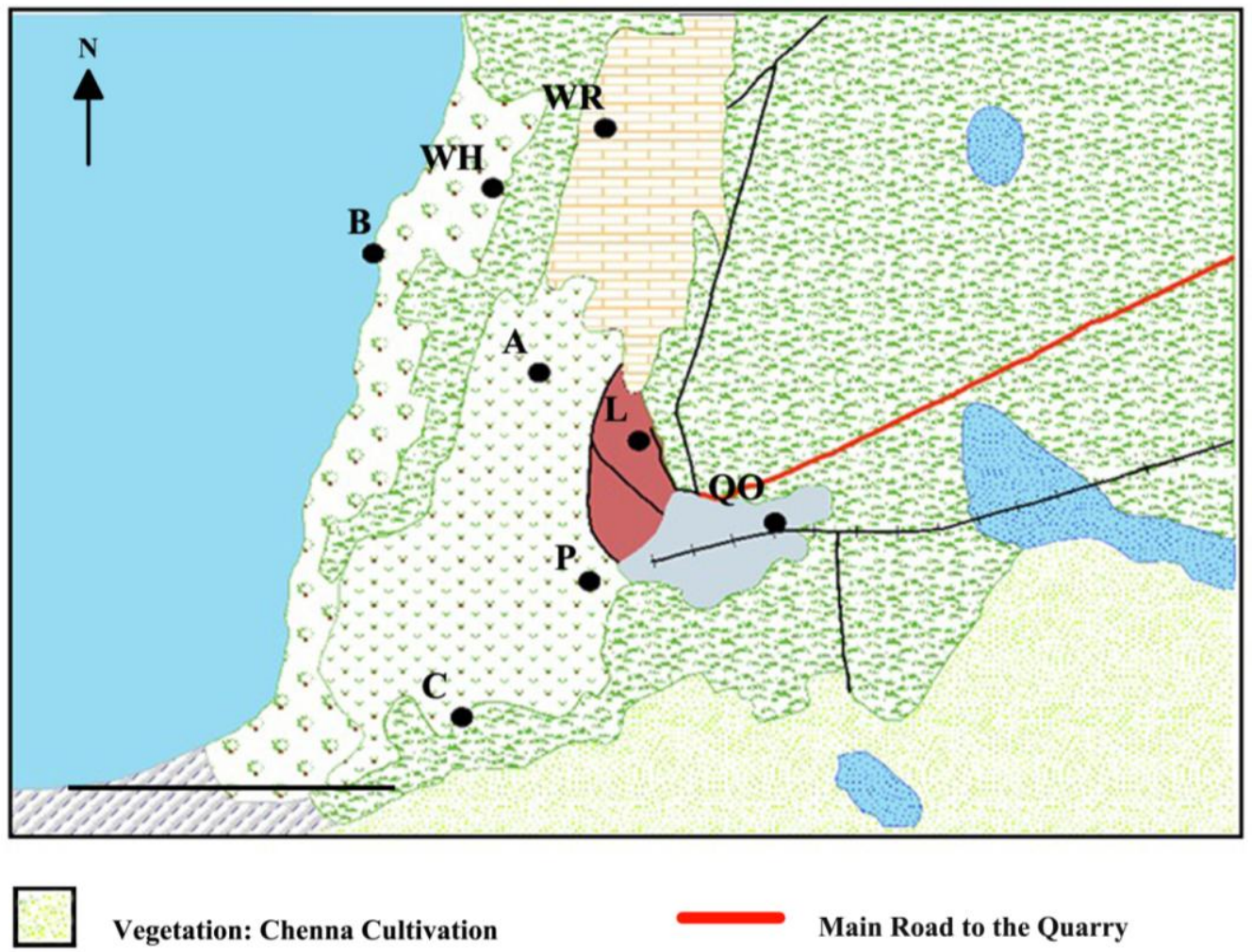

Vegetation: Chenna Cultivation

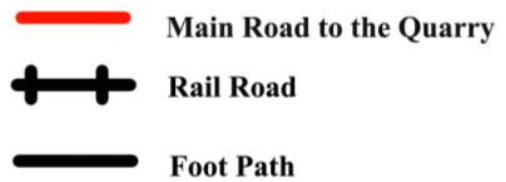

Vegetation: Shrub Forest

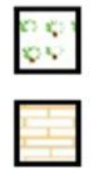

Vegetation: Coconut Cultivation

Working Area

Excavated Area

Wetlands/Temporary Water Bodies

Quarry Office \& Loading Site

QO
P
A
L
C
WH
WR
B

Foot Path

\section{Residential Area}

Quarry Office

Peella Site

Alahakoon Site

Lasantha Site

Coral Site

Waterhole Site

Working Site

Beach Site

Figure 2. Distribution of study sites within the study area at Aruwakkalu. (Scale bar $1 \mathrm{~km}$ ) 
Peella site, located $0.60 \mathrm{~km}$ southwest of the base, contained an excavated wall with a clear view of the sedimentary profile. This wall extends throughout the site but in some areas it is obscured by dumped limestone and red earth. The Alahakoon site, located $0.85 \mathrm{~km}$ northwest of the base, contained an extensive wall but the sedimentary profile was not very clear. The Water hole site, located $1.37 \mathrm{~km}$ northwest of the base, was a filled up quarry site; thus it did not contain a clear sedimentary profile. However, there were fossiliferous rocks which had fallen from the wall during limestone extraction. The Coral site, located $1.10 \mathrm{~km}$ southwest of the base, was a very small exposure and did not contain a clear sedimentary profile. The Beach site, located $1.50 \mathrm{~km}$ northwest of the base, included mainly fossiliferous intertidal rocks, along the eastern coast of Dutch Bay, which were exposed during low tide. The Lasantha site, located $0.47 \mathrm{~km}$ northwest of the base, was represented by an extensive wall with a clear sedimentary profile. The Working site, located $1.37 \mathrm{~km}$ northwest of the base, is the one from which limestone is currently being extracted.

\section{Collection and identification}

The study area was surveyed over a period of eight days. Fossils were both handpicked and unearthed by digging through the limestone already excavated. Two collections were made, a general collection and a timeline collection. In the general collection, fossils found scattered on the ground were collected from each site. In the timeline collection, fossils found on the walls of the study sites were collected from the uppermost layer down to the lowest fossiliferous layer in a vertical profile.

Fossils collected were carefully wrapped to prevent abrasion and chipping while in transport. Fossils of the timeline collection were placed in separate zip-lock bags based on the layer from which they were extracted.

Each fossil was catalogued with a reference number and a photograph. Other information included date of collection, site of collection, names of collectors and reference number of the relevant photograph. The collection was identified using paleontological literature (Carter, 1853; Banner and Highton, 1989; Renema, 2008; and Hottinger, 2006). Morphological and morphometric data were obtained using the software program ImageJ.

\section{RESULTS}

\section{Stratigraphy}

The soil profile at the seven surveyed sites comprised of six sedimentary layers. Of these, only two layers contained fossils, the sixth (the deepest layer, containing predominantly gastropods, referred to as the gastropod layer, Fig. 3); and the third (dominated by giant oysters, referred to as the giant oyster layer, Fig. 4).

\section{Fossils of foraminifera}

Fossils of $P$. malabarica were included in both the timeline and the general collections (see Table 1). Microspheric forms were recovered from the timeline collection at Alahakoon site, while megalospheric forms were recovered from general collection at Peella site.

\section{Systematic paleontology}

Family-Soritidae Ehrenberg, 1839

Genus- Pseudotaberina Eames, in Davies 1971, emend. Banner and Highton, 1989

Species- P. malabarica

Repository- Material collected in this study are deposited in the Zoological Collection of the Department of Zoology (University of Peradeniya) (Table 2).

\section{Microspheric form: AR0098, AR0104}

Megalospheric form: AR0237, AR0065, AR0047

Locations- See Table 1

\section{Description}

Microspheric form Specimens (fossil reference number AR0098, Fig. 5 and fossil reference number AR0104, Fig. 6 ) represented by equatorial sections; shell initially planispiral, becoming annular distally. Chamberlets of annular chambers visible to the periphery of the mould and stolon axes or axes of intercameral foramina Y-shaped, not parallel to the radius of the test (Fig. 5). Test flat and discoid, diameter reaching up to $16.010 \mathrm{~mm}$ (Fig. 5). 


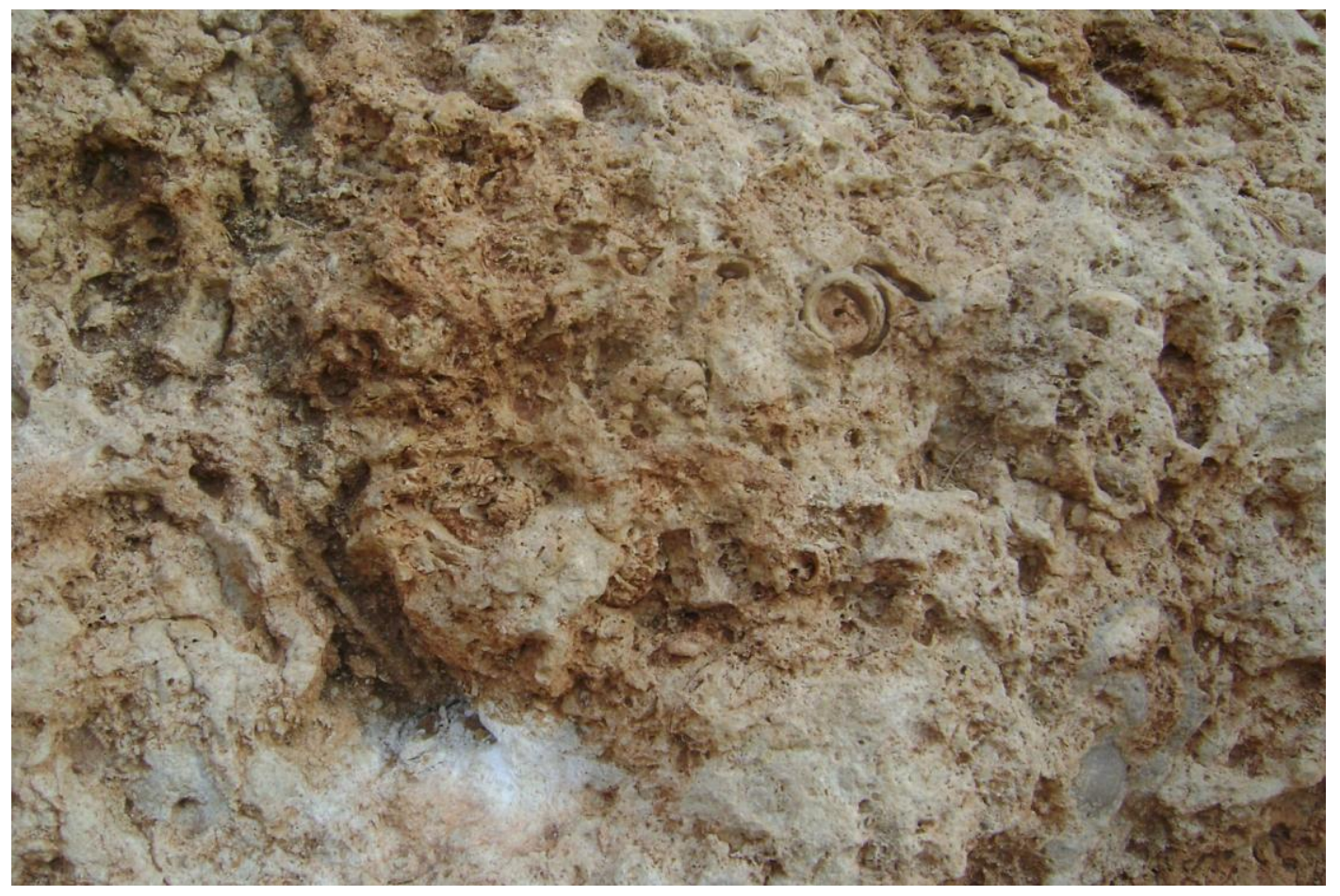

Figure 3. Sixth layer of the sedimentary profile at Aruwakkalu: layer dominated by fossils of gastropods.

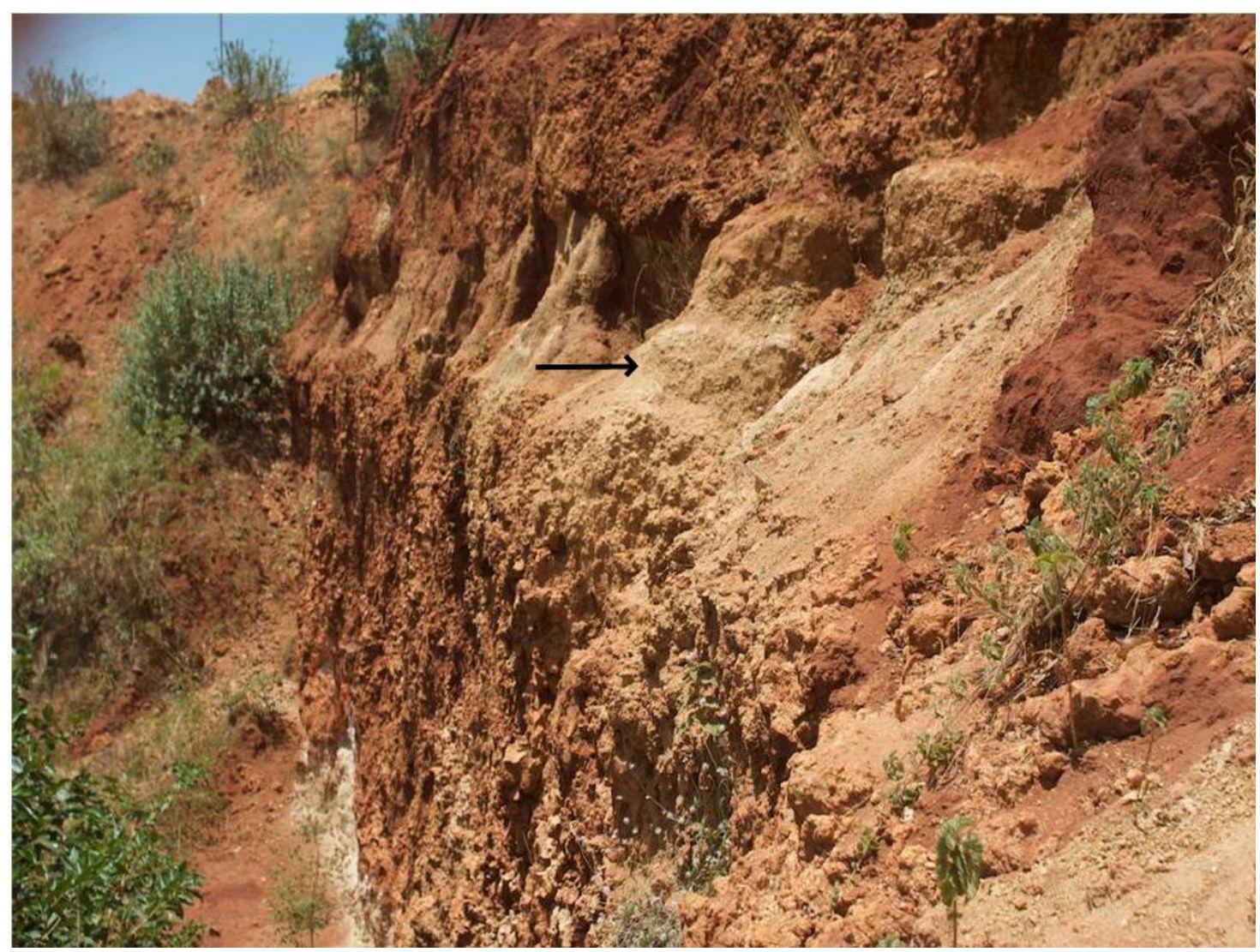

Figure 4. Third layer of the sedimentary profile at Aruwakkalu (Indicated by arrow). 
Megalospheric form: Specimens represented by transverse, axial and oblique sections (fossil reference number AR0237, Figures 7, 8 and 9). In the axial section, the large megalosphere at center; planispiral involute growth observed where initial chambers are embraced by successive chambers. Megalosphere and initial chamber arrangement also observed in oblique section. Specimens (fossil reference number AR0065, Fig. 10 and fossil reference number AR0047, Fig. 11) represent moulds of the shell cavity occupied by the system of intercameral foramina and chamberlet lumina indicating the Y-shaped arrangement of stolon axes. Chamber walls eroded.
Measurements - Test diameter, $4.841 \mathrm{~mm}$ (AR0237: Fig. 7).

Other material examined- See Table 2

Remarks: The collection comprised approx. 40 individuals, collected from general and timeline collections at Peella and Alahakoon sites. Of the 40, two large clusters were recovered comprising of $12-15$ and 13 individuals, respectively.

Fossils of Pseudotaberina malabarica recorded from Sri Lanka thus far include specimens from Kirimalai, Puttalum, Pomaparippu and Pallai (Banner and Highton, 1989).

Table 1. Number of Pseudotaberina malabarica collected from each site within the study area.

\begin{tabular}{llll}
\hline Fossil reference No. & Number of fossils & Location & Layer/Collection method \\
\hline AR0047 & $12-15$ & Peella site & General Collection \\
AR0065 & 4 & Peella site & General Collection \\
AR0098 & 2 & Alahakoon site & Gastropod layer \\
AR0104 & 4 & Alahakoon site & Gastropod layer \\
AR0123 & 1 & Peella site & Gastropod layer \\
AR0236 & 1 & Unknown & Unknown \\
AR0237 & 13 & Unknown & Unknown \\
\hline
\end{tabular}

Table 2. Life stages and dimensions of Pseudotaberina malabarica collected from the study area.

\begin{tabular}{|c|c|c|c|}
\hline Fossil Reference No. & Figure No. & Generation & Test diameter $(\mathrm{mm})$ \\
\hline AR0098 & 5 & Microspheric & 16.01 \\
\hline AR0104 & 6 & Microspheric & 17.14 \\
\hline AR0237 & 7 & Megalospheric & 4.84 \\
\hline AR0237 & 8 & Megalospheric & 3.13 \\
\hline AR0237 & 9 & Megalospheric & - \\
\hline AR0065 & 10 & Megalospheric & - \\
\hline AR0047 & 11 & Megalospheric & - \\
\hline
\end{tabular}




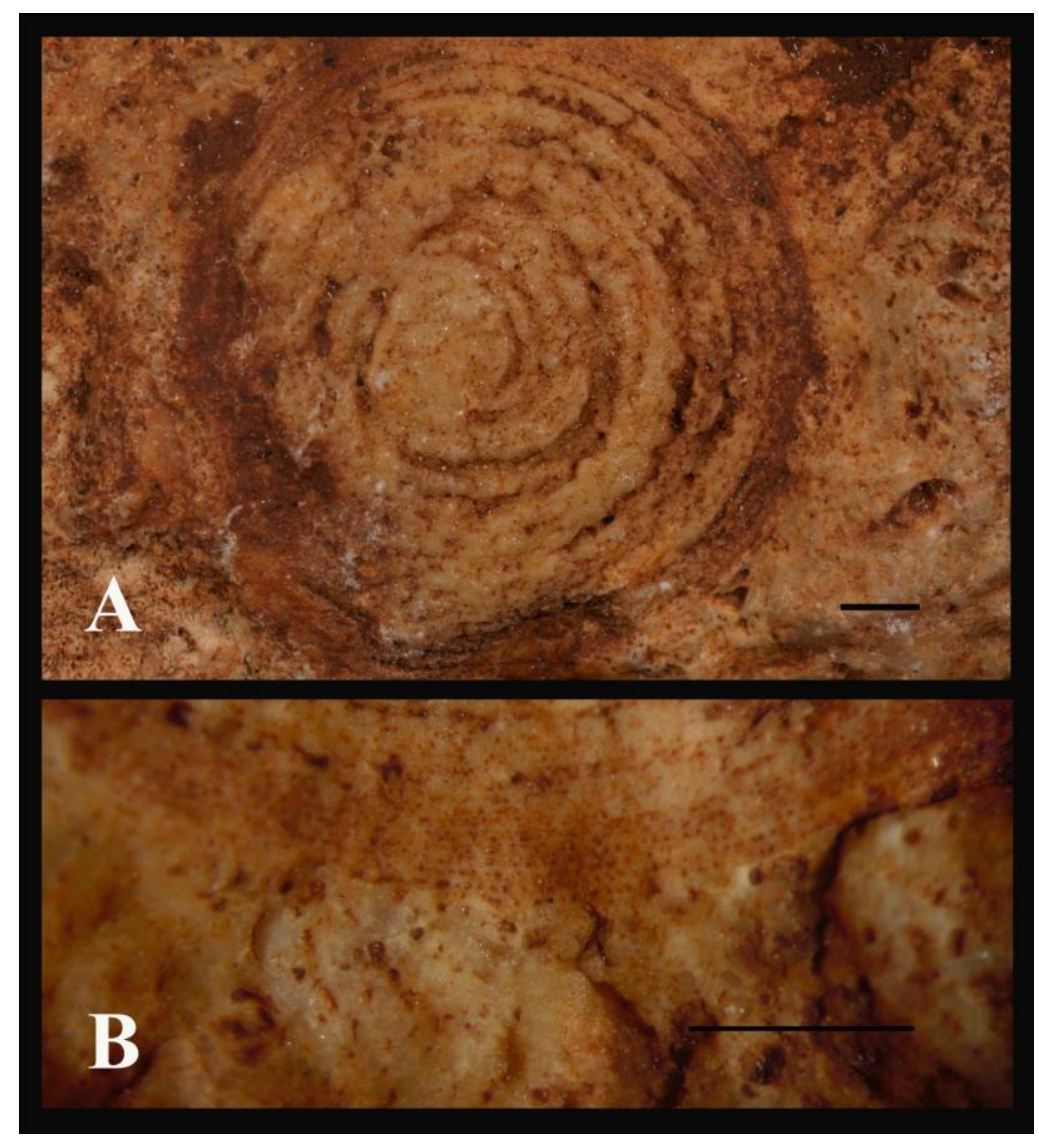

Figure 5. (A) Fossil Reference No. AR0098. Equatorial section of a microspheric form (see Section on Systematic Paleontology). (B) Magnified portion of the image in Fig. 5A, focused on chamberlets (scale bar $2 \mathrm{~mm}$ ).

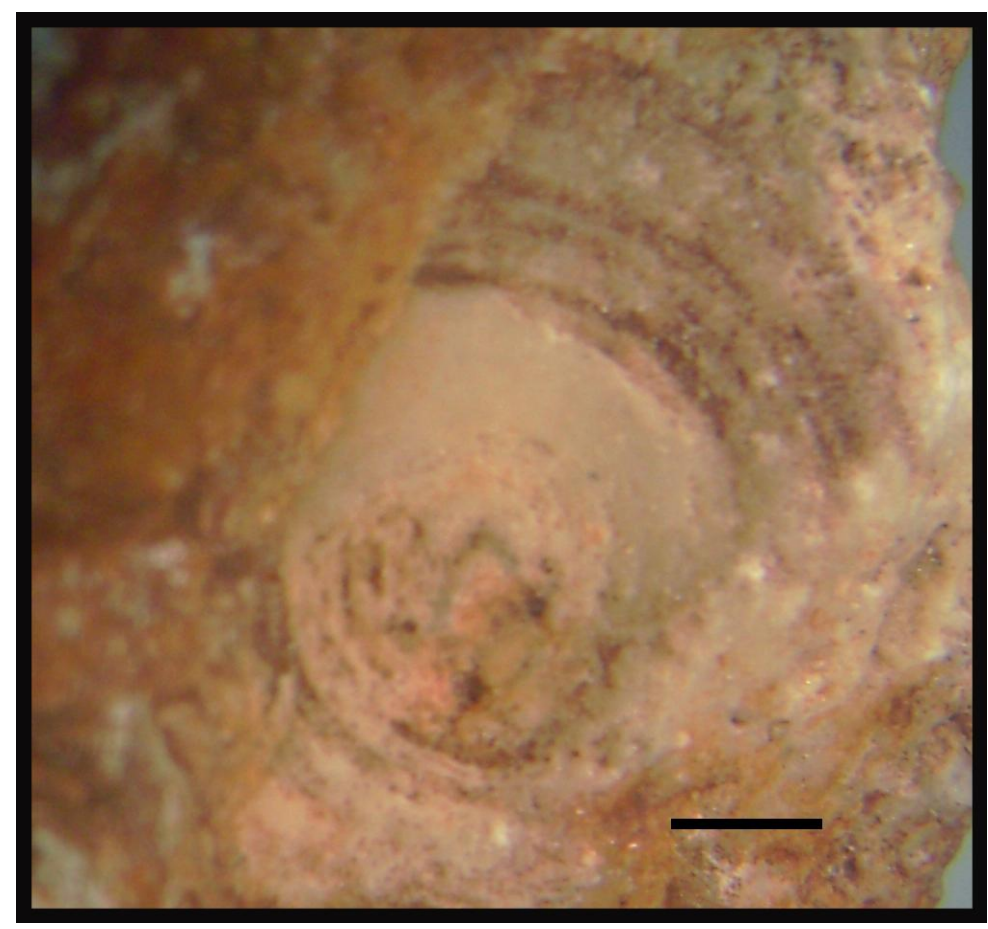

Figure 6. Fossil Reference No. AR0104 (X6). Equatorial section of a microspheric form (scale bar 2 mm). 


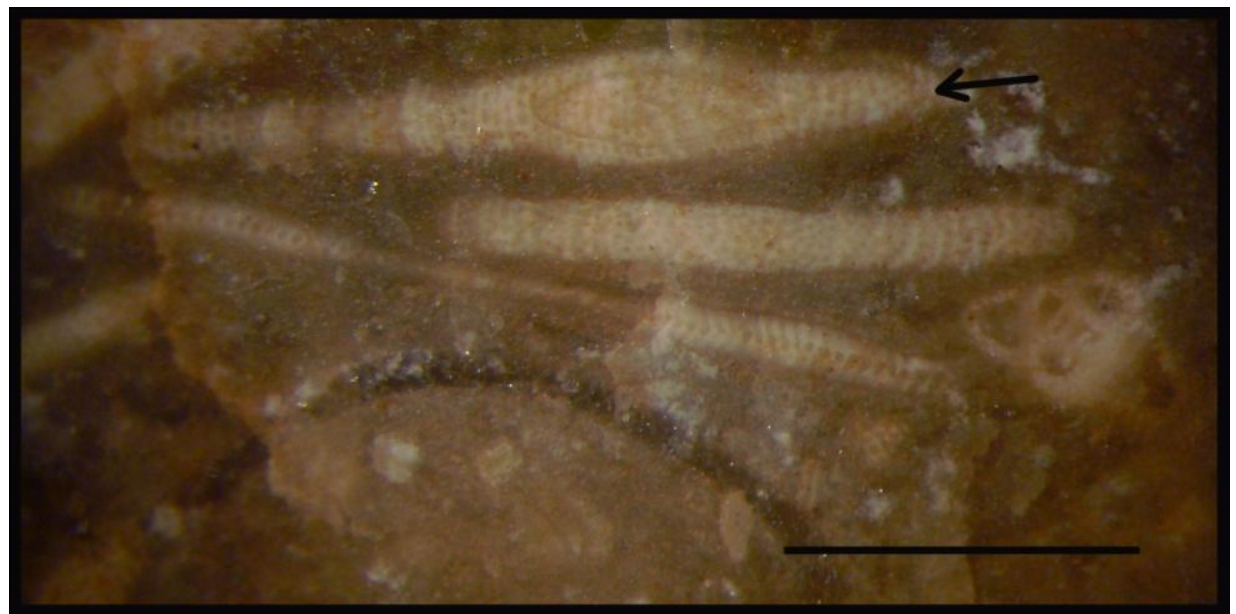

Figure 7. Fossil Reference No. AR0237. Transverse section of a megalospheric form. Specimen indicated by arrow (scale bar $2 \mathrm{~mm}$ ).

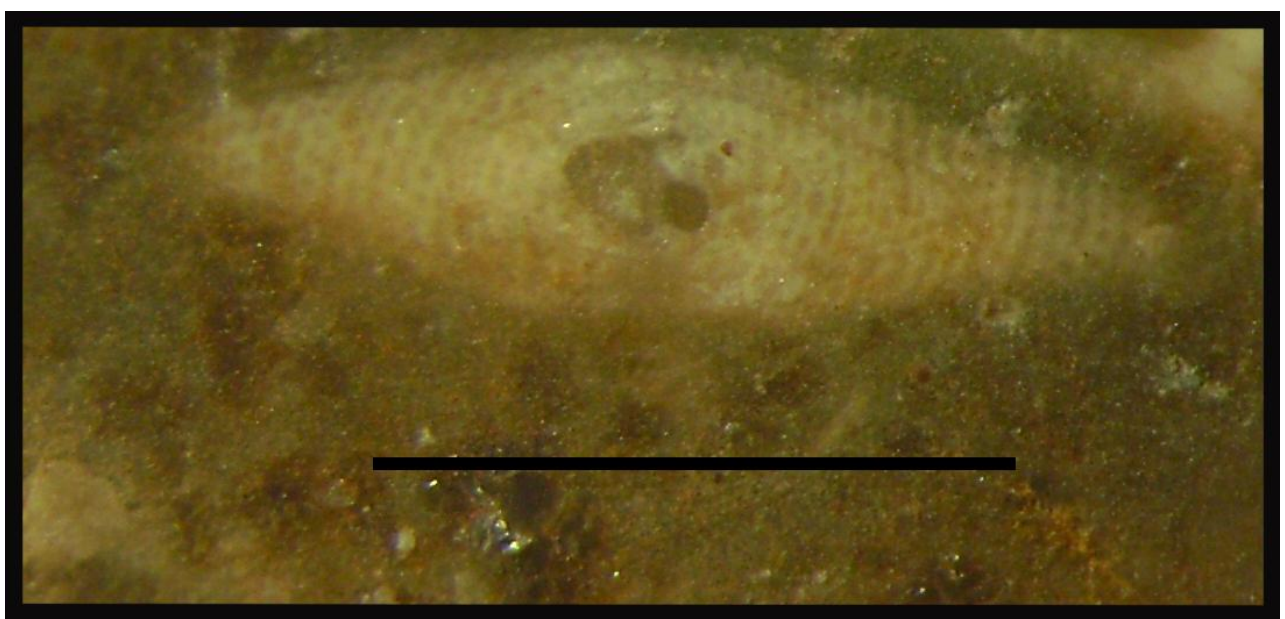

Figure 8. Fossil Reference No. AR0237. Axial section of megalospheric generation showing the initial involute growth (scale bar $2 \mathrm{~mm}$ ).

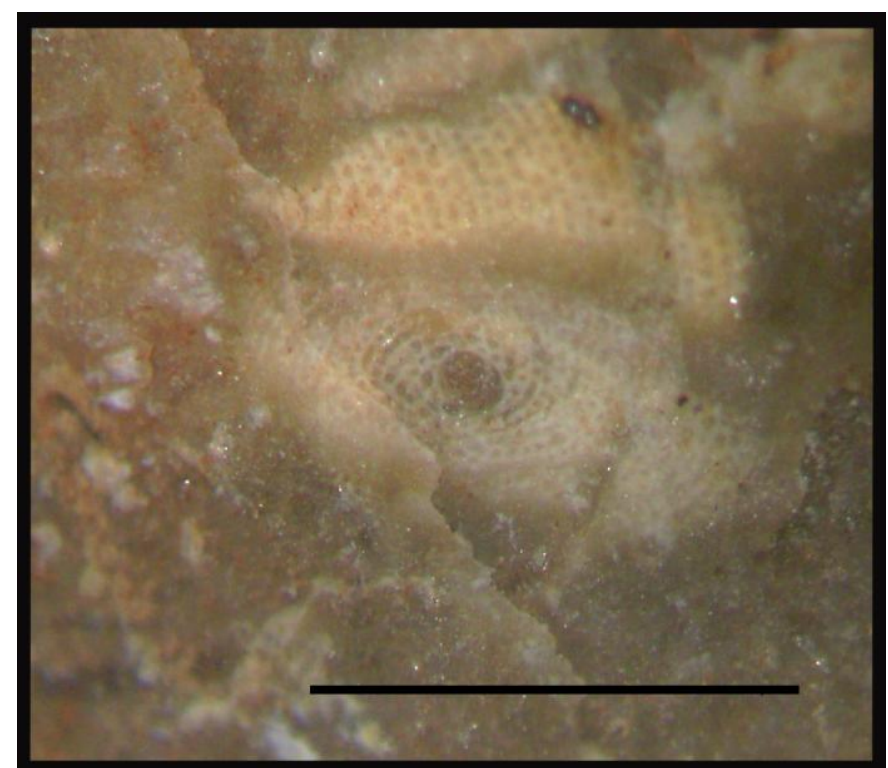

Figure 9. Fossil Reference No. AR0237. Oblique central section of a megalospheric shell (scale bar 2 $\mathrm{mm})$. 


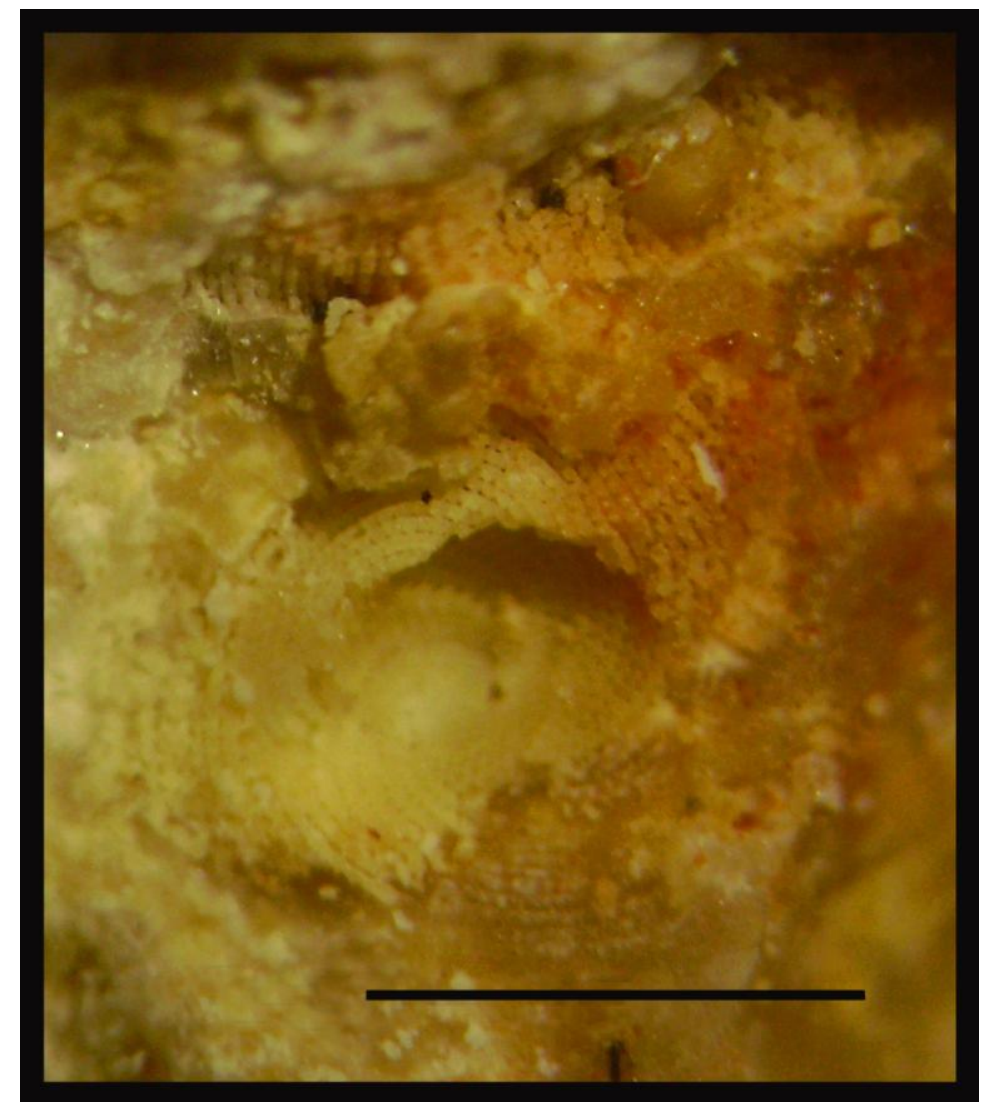

Figure 10. Fossil Reference No. AR0065. Internal mould of a planispiral megalospheric shell, upper part not preserved (scale bar $2 \mathrm{~mm}$ ).

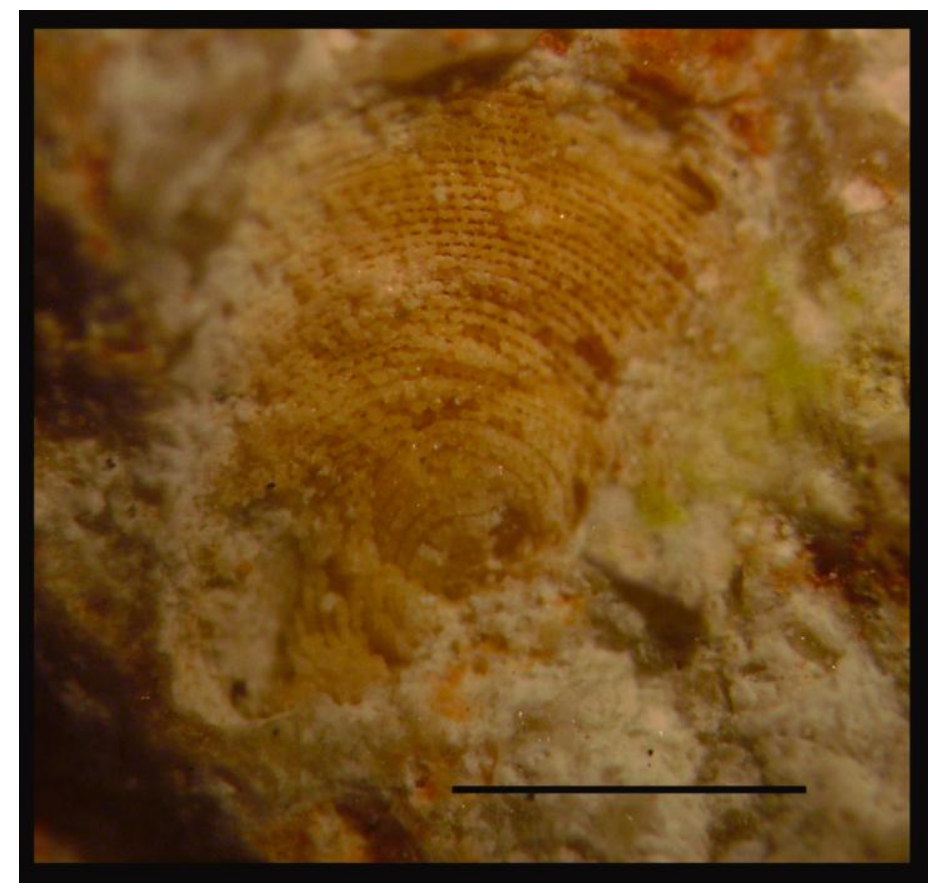

Figure 11. Fossil Reference No. AR0047. Equatorial section of an internal mould of a planispiral megalospheric shell (scale bar $2 \mathrm{~mm}$ ). 


\section{DISCUSSION}

Sri Lanka's northern Tertiary deposit is vast, composed of fossiliferous limestone that hosts fossils dating to the Miocene and late Pleistocene. Surveys by early explorers recovered fossils of both invertebrates and vertebrates, of which the latter are considered important because the earliest vertebrate fossils found in Sri Lanka date to the Miocene (Deraniyagala, (1969b). Being a marine deposit, Aruwakkalu contains a wide variety of marine fossil fauna ranging from foraminifera to mammals. However this study focuses on the index fossil Pseudotaberina malabarica, an extinct foraminifer based on which Sri Lanka's Miocene was dated.

In this study, the index fossil foraminifer Pseudotaberina malabarica was discovered from both timeline and general collections. In the timeline collection, fossils of the index fossil were recovered only from the gastropod layer. Two additional unidentified fossil foraminifera were found in the gastropod layer at the Lasantha site. Since general collections do not provide information on the stratigraphical occurrence of fossils, it is likely that $P$. malabarica only existed during the time at which the gastropod layer was being laid down. Therefore, the gastropod layer can be confirmed as a part of the Burdigalian. Hence the superficial giant oyster layer could be of a more recent age than the gastropod layer, since the two fossiliferous layers flank two other sedimentary layers between them. However, the Burdigalian occupies the time period of about four million years, hence the layers immediately above the gastropod layer could have formed during the Burdigalian if the sedimentation rates were rapid. The exact time frame of the giant oyster layer cannot be determined with certainty at present. According to Deraniyagala (1969a), deposits belonging to Pliocene and Pleistocene are present above the Miocene at Aruwakkalu. Deraniyagala, without listing the entire composition of this late Pleistocene deposit, stated that it contained recent taxa such as Anadara granosa. However, fossils of Anadara granosa could not be discovered from the oyster layer in the present study. Further, in another communication (Deraniyagala, 1969b), a relatively young superficial estuarine deposit is mentioned, which is probably the same late Pleistocene deposit mentioned above. This deposit is said to occupy 240 feet $(73 \mathrm{~m})$ above sea level and was mentioned as being composed of unweathered molluscan shells. However, the oyster layers at both the Peella and the Lasantha sites were situated at heights less than $30 \mathrm{~m}$ above sea level, and fossils recovered were weathered. It therefore appears that the oyster layer is not a part of the late Pleistocene. Information on sedimentation rate could help in placing this layer within or outside the Miocene (23.0-5.3 mya). Further the presence of the late Pleistocene (Quaternary) deposit above the Miocene should be recognized.

In paleontology, an ideal index fossil should possess several characters such as being abundant in the stratigraphic record, easily distinguishable from other related species, geographically widespread and having a narrow stratigraphical range (Stanley, 2005). The fossil foraminifer $P$. malabarica possesses all of the above, making it an excellent fossil for dating a sedimentary layer

Relative dating of the Tertiary limestone in Sri Lanka initially placed the deposit at the Cretaceous and Eocene (see Deraniyagala, 1969a). Then Wayland classified it as Miocene based on faunal composition (see Deraniyagala, 1969a). Wayland and Davies examined the Jaffna limestone, which contained fossils of Taberina malabarica (Pseudotaberina malabarica), but they overlooked the foraminifer and classified it as a part of the Vindobonian (Kulkarni et al., 2010; Mohan and Chatterji, 1956). Cotter, in 1938 considered the Jaffna limestone to be of upper Vindobonian age (Mohan and Chatterji, 1956 ). Eames (1950) reexamined Davies' collection and admitted the importance of Archaias malabaricus (Pseudotaberina malabarica), which led to the current classification of the Jaffna limestone as Burdigalian.

Pseudotaberina malabarica is considered an important taxon in environmental reconstruction. All larger benthic foraminifera are marine and neritic, living largely in oligotrophic reef and carbonate shoal environments (BoudagherFadel, 2008). However, these foraminifera are today confined mainly to lower latitudes (Boudagher-Fadel, 2008). Some large foraminifera posses symbionts within their chambers. Thus, their distribution depends on factors such as temperature, nutrient levels, light and water depth. Larger benthic foraminifera are biofacies bound and have biotopes closely associated with carbonate environments (Boudagher-Fadel, 2008). They are also considered as excellent indicators of paleoenvironments. Ecological studies carried out on larger extant foraminifera suggest that the minimum water temperature tolerated is $18{ }^{\circ} \mathrm{C}$, while the maximum water depth habitable is 35 m (Boudagher-Fadel, 2008). Further, 
Pseudotaberina malabarica has an epiphytic mode of life: in large aggregations they are considered as indicators of sea-grass vegetation (Reuter et al., 2010), which has hitherto not been recorded from the Miocene of Sri Lanka. Therefore, both Peella and Alahakoon sites can be assumed to have possessed sea grass beds during the Burdigalian.

The dimorphic forms of fossilized Pseudotaberina malabarica were identified considering their test diameter and internal and external shell architecture. In the microspheric form, planispiral involute growth starts closely around the small proloculus and become cyclical and evolute in the latest growth stage resulting in a flat or even biconcave discoid test. In the megalospheric form, the test is initially biconcave with the first chamber initially developing into a protoconch, followed by a second reniform growth stage forming a deutoroconch, and these are followed by planispiral chambers (Banner and Highton, 1989; Hottinger, 2005). Specimens of megalospheric forms have been reported to reach a diameter of up to $6.5 \mathrm{~mm}$ and a thickness of $0.7 \mathrm{~mm}$ while microspheric specimens can reach a diameter of up to $15 \mathrm{~mm}$ (Renema, 2008). However, larger specimens with maximum diameters reaching up to $21 \mathrm{~mm}$ have been recorded by Wayland and Davies (Renema, 2008).

\section{CONCLUSION}

The Tertiary and Quaternary exposures along the northwestern of part of Sri Lanka is composed of both Miocene and late Pleistocene deposits. Miocene fossils belonging to the Burdigalian were recovered only from the gastropod layer, which is overlaid by a deposit of giant oysters, possibly older than the late Pleistocene but of unconfirmed age. Thus, the northwestern exposures of Sri Lanka probably comprise of three deposits belonging to three time frames, a Burdigalian gastropod layer, a late Pleistocene estuarine deposit and an intermediate giantoyster layer.

Fossils of the index foraminifer Pseudotaberina malabarica recovered from the gastropod layer confirm the Burdigalian age of this deposit. However, our results show that the entire Tertiary deposit of northwestern Sri Lanka cannot, at present, be referred to the Burdigalian with certainty.

\section{ACKNOWLEDGEMENTS}

We are grateful to Mr. Athula Janz, Mr. Chalaka Fernando and Holcim Lanka Pvt. Ltd. for giving us access to study fossils within the Aruwakkalu quarry site. We thank Prof. Ranjith Dissanayake for support with initiating this study. We greatly value the comments by Dr. G. L. Badam and Mr. Rohan Pethiyagoda, reviewers of the paper. We acknowledge Mr. Gayan Bowatte for his kind contribution towards fieldwork and preparation of the figures and to Prof. Nimal Gunatilleke and Prof. Savitri Gunatilleke for support with logistics. This study was entirely self-funded by the authors.

\section{REFERENCES}

Banner, F. T. and Highton, J. (1989). On Pseudotaberina malabarica (Carter) (Foraminiferida). Journal of Micropalaeontology 8(1): 113-129.

Bhatia, S. R. and Mohan, K. (1959). Miocene (Burdigalian) Foraminifera from Kathiawar, Western India. Journal of Paleontology 33(4): 641-661.

Boudagher-Fadel, M. K. (2008). Evolution and Geological Significance of Larger Benthic Foraminifera, In: P. B. Wignall (Ed.). Developments in Palaeontology and Stratigraphy, $1^{\text {st }}$ edition. Elsevier, Amsterdam, The Netherlands, Pp.1-38.

Brock, V. (1990). Intergeneric distances between Ostrea, Crassostrea, and Saccostrea, studied by means of crossed immuno-electrophoresis. Marine Ecology Progress Series 68: 59-63.

Carter, H. J. (1853). A description of Orbitolites malabarica (H.J.C.), illustrative of the spiral and not concentric arrangement of chambers in d'Orbigny's order Cycloste'gues. Annals and Magazine of Natural History 2: 425-427.

Cooray, P. G. (1984). An Introduction to the Geology of Sri Lanka (Ceylon). $2^{\text {nd }}$ revised edition, National Museums Department Colombo. Pp. 126-133.

Deraniyagala, P. E. P. (1937). Some Miocene and Upper Siwalik Vertebrates from Ceylon. Spolia Zeylanica 20: 191-198.

Deraniyagala, P. E. P. (1937). Some Miocene fishes from Ceylon. Spolia Zeylanica 20(3): 355-367.

Deraniyagala, P. E. P. (1961). The Amphitheatres of Minihagal Kanda, their possible origin and some of the fossils and stone artifacts collected from them. Spolia Zeylanica 29(2): 149-161. 
Deraniyagala, P. E. P. (1969a). Some aspects of the Tertiary Period in Ceylon. Journal Royal Asiatic Society (Ceylon Branch) 2(12): 86108.

Deraniyagala, P. E. P. (1969b). A Miocene vertebrate faunule from the Malu member of Ceylon. Spolia Zeylanica 31(2): 551-570.

Eames, F. E. (1950). On the Ages of certain upper Tertiary beds of peninsular India and Ceylon. Geological magazine 87(4): 233-252.

El-Hedeny' M. M. (2005). Taphonomy and paleoecology of the Middle Miocene oysters from Wadi Sudr, Gulf of Suez, Egypt. Revue de Paléobiologie 24 (2): 719-733.

Hottinger, L (2005). Geometrical constraints in foraminiferal architecture: consequences of change from planispiral to annular growth. Studia geologica polonica 124: 99-115.

Hottinger, L. (2006). Illustrated glossary of terms used in foraminiferal research, Viewed 25 October 2011.

<http://paleopolis.rediris.es/cg/CG2006_M02/i ndex.html >

Ivanov, M., Hrdlickova, S and Gregorova, R. (2004). The Complete Encyclopedia of Fossils. $2^{\text {nd }}$ edition, Rebo internatonal b.v., Lisse, The Netherlands. Pp.312.
Kulkarni, K. G., Kapoor, S. B. and Borkar, V. D. (2010). Molluscan fauna from the Miocene sediments of Kachchh, Gujarat, India. Journal of Earth System Science 119(3): 307-341.

Madduma Bandara, C. M. (1989). A survey of the coastal zone of Sri Lanka. Coast Conservation Department, Sri Lanka, pp. 1-3.

Mohan, K. and Chatterji, A. K. (1956). Stratigraphy of the Miocene Beds of Kathiawar, Western India. Micropaleontology 2(4): 349-356.

Renema, W. (2008). Internal architecture of Miocene Pseudotaberina and its relation to Caribbean Archaiasins. Palaeontology 51 (1): 71-79.

Reuter, M., Piller, M. W., Harzhauser, M., Kroh, A., Rogl, F. and Coric, S. (2010). The Quilon Limestone, Kerala Basin, India: an archive for Miocene Indo-Pacific seagrass beds. Lethaia 44 (1): 76-86.

Stanley, S.M. (2005). Earth System History. $2^{\text {nd }}$ Edition. W.H. Freeman and Company, New York. Pp. 135.

Siddiqui, G. and Ahmed, M. (2002). Oyster species of the sub tropical coast of Pakistan (Northern Arabian sea). Indian Journal of marine science 31(2): 108-118. 